\title{
RODOPIANDO COM O “SACI-PERERÊ": MOVIMENTOS DO BRINCAR NA EDUCAÇÃO INFANTIL
}

F.T. ROVERI
Universidade Estadual de Campinas (UNICAMP)
ferdth@yahoo.com.br
Artigo submetido em novembro/2014 e aceito em novembro/2014
DOI: $10.15628 /$ holos.2014.2524

\section{RESUMO}

Os contos e as lendas do folclore brasileiro apresentam uma riqueza ímpar tanto de personagens quanto de temas e permitem que trechos e traços da história nacional sejam trazidos em suas singularidades $e$ universalidades. A lenda do "Saci-Pererê", representada por um menino negro de uma perna só e que fuma um cachimbo, nasce da mestiçagem brasileira, da fusão de etnias, culturas, conhecimentos, crenças e valores em que uma geografia se impõe (CASCUDO, 1954; MEIRELES, 1983; ANDRADE, 1976). A ideia da liberdade é representada por esse personagem que aparece $\mathrm{e}$ desaparece com o vento, fazendo peraltices por meio dos poderes mágicos de seu gorro vermelho. Esse trabalho tem como objetivo narrar uma experiência pedagógica realizada com crianças de 02 a 06 anos de idade, em uma escola pública do município de Campinas-SP, a partir de procedimentos de ensino realizados com contos e lendas do folclore. Diversos personagens, como o "Saci-Pererê", a "Cuca" e o "Boitatá", ganharam vida por meio da imaginação, aparecendo em nosso cotidiano e instigando diversas brincadeiras com as crianças, como as de aparecer e desaparecer com o vento, saltitar, fazer mágicas e misturar os brinquedos, por exemplo. Concluímos que, ao aproximarmos as crianças das manifestações folclóricas presentes em nosso dia-a-dia valorizamos outros conhecimentos, abrindo caminhos diferentes para curiosidades e experiências infantis (BOSI, 1992; KISHIMOTO, 1998). Como resultado desse trabalho, percebemos o enriquecimento do repertório das brincadeiras infantis e o interesse e a participação da comunidade com suas vivências, lembranças e narrativas que constituem memórias da infância.

PALAVRAS-CHAVE: educação infantil, cultura, brincar, folclore, imaginação.

\section{WHIRLING WITH “SACI-PERERÊ”: PLAYNG IN PRESCHOOL}

\begin{abstract}
Short stories and tales of the Brazilian folklore present a unique abundance of characters as well as themes and bring excerpts and traces of the national history in their singularities and universalities. The legend of "SaciPererê", represented by an one-legged black boy who smokes a pipe is born from the Brazilian miscegenation, from the fusion of different ethnicities, cultures, knowledge, beliefs and values to which a particular geography imposes itself (CASCUDO, 1954; MEIRELES, 1983; ANDRADE, 1976). The idea of freedom is represented by this character that appears and disappears with the wind, doing mischievousness by using magical powers originated from his red cap. This paper aims to narrate a pedagogical experience carried out with children aged between 2 and 6 in a public school of the city of Campinas-SP, based on teaching procedures
\end{abstract}

by which characters of the Brazilian folklore, such as "Saci-Pererê", "Cuca" and "Boitatá", came to life through imagination, appearing in our daily activities and instigating different playing forms with the children, such as appearing and disappearing with the wind, hopping, doing magic tricks and scrambling their toys, for instance. We came to the conclusion that by bringing the children closer to the folkloric manifestation present in our everyday we can value other knowledge, opening different paths for children's curiosities and experiences (BOSI, 1992; KISHIMOTO, 1998). As a result from this work we've noticed the enrichment of our repertoire of activities with the children, as well as the interest and participation of the community with its experiences, memories and narratives that constitute memories of childhood.

KEYWORDS: preschool, culture, playing, folklore, imagination. 


\section{INTRODUÇÃO}

Esse trabalho apresenta algumas vivências infantis com os contos e lendas do folclore brasileiro, a partir de memórias e reflexões de minha prática docente na Educação Infantil com crianças de 02 a 06 anos em uma escola pública de Campinas-SP.

Considerando que os contos e as lendas do folclore brasileiro apresentam uma riqueza ímpar tanto de personagens quanto de temas e permitem que trechos e traços da história nacional sejam trazidos em suas singularidades e universalidades, registraremos aqui um conjunto de práticas que percebe no folclore o conhecimento do povo em suas manifestações de vida, como descreveu Cecília Meireles ${ }^{1}$ (1983). Narraremos assim, um pouco do vivido com as crianças a partir de histórias e brincadeiras que trazem como enredo o Saci-Pererê.

Em sua vasta trajetória como folclorista, Luís da Câmara Cascudo (1954) registrou no Dicionário do Folclore Brasileiro algumas singularidades desse personagem, o qual pode ser uma entidade maléfica em algumas oportunidades e alegre ou zombeteira em outras. Saci-Pererê, proveniente de narrativas dos estados do Sul do Brasil e de alguns países vizinhos ${ }^{2}$, é um menino negro com uma só perna, fuma um cachimbo e possui uma carapuça vermelha que lhe dá poderes mágicos, como agilidade, astúcia e invisibilidade. Pode-se suspeitar de sua presença principalmente quando ocorrem ventanias e redemoinhos, além de sinais como fortes assobios, trançados nas crinas dos cavalos, comidas queimadas na panela e objetos perdidos.

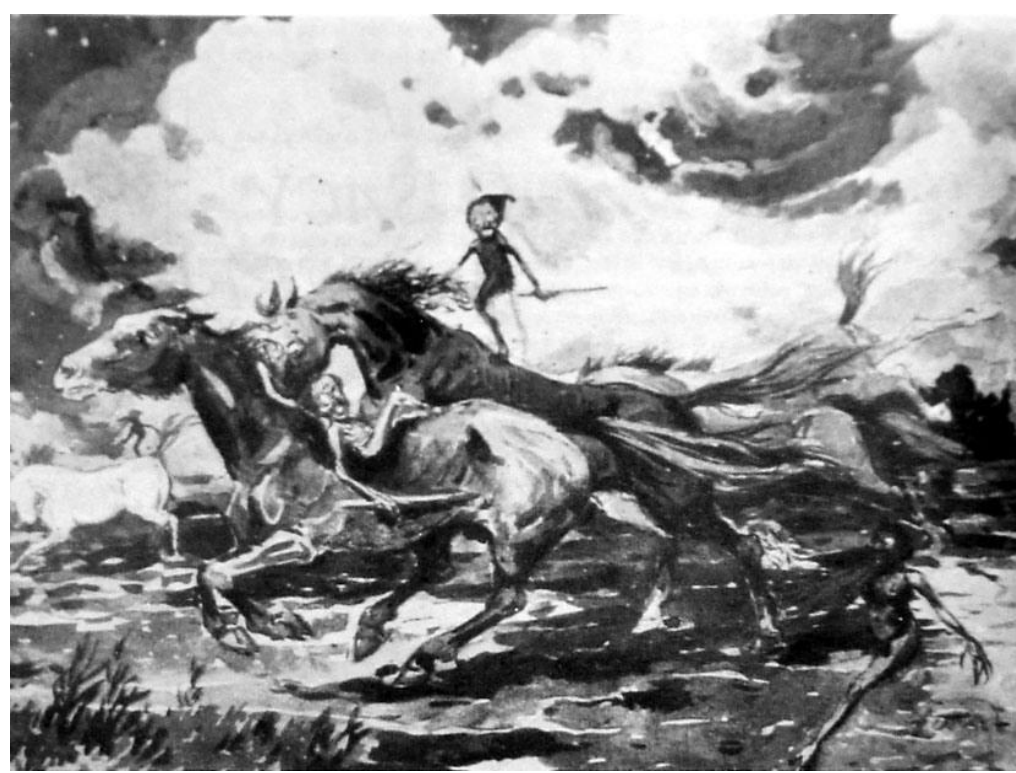

Figura 1: Alfredo Narofini. Saci na cavalhada. Pintura sobre papel, 1917.

\footnotetext{
${ }^{1}$ Cecília Meireles (1901-1964) teve uma trajetória abrangente, figurando como poetisa, cronista, crítica literária, tradutora, educadora e folclorista. Envolveu-se em importantes movimentos educacionais brasileiros, como o Manifesto dos Pioneiros da Educação Nova (1932) e o Movimento Folclórico Brasileiro (1947-1967). Ver Vieira, 2013. ${ }^{2}$ Além de países como Argentina, Uruguai, Chile e Paraguai, Cascudo (1983) identifica que características do Saci (invisível, de uma só perna, ágil, travesso, vermelho) também em estão presentes em alguns elfos, trolls e gnomos do folclore europeu. $\mathrm{O}$ autor descreve que a etnografia registrou inúmeros seres como esse em contos da Alemanha, França, Portugal e Escandinávia, criaturas maravilhosas que constituem "um mundo atordoante de pequeninos seres poderosos, perversos ou atormentadores, vivendo derredor dos homens civilizados e orgulhosos de sua civilização" (CASCUDO, 1983, p.108).
} 
Juntamente com o Saci, apresentamos às crianças outros personagens que povoam matas e florestas, como Boitatá - cobra com olhos de fogo; Curupira - anão de cabelos vermelhos e pés virados para trás, protetor da floresta; Cuca - bicho papão que amedronta as crianças que não dormem; dentre outros, os quais também fizeram parte de nosso repertório de brincadeiras, músicas e histórias.

Ao discutir a valorização do patrimônio arqueológico brasileiro, Meneses (1992) sublinha a necessidade de preservação dos bens culturais não com fins de conhecimento do passado, mas como o conhecimento da dimensão temporal do homem. Assim, concordando com o autor, pensamos um trabalho com contos e lendas do folclore brasileiro como formas de memória, pertencimento e reapropriação:

O homem não é um ser abstrato, que viva em levitação, mas se enraíza em espaços determinados, espaços que vêm assim a funcionar como suporte de comunicação, de inter-relação, de organização de sentido e, enfim, de fecundidade: terra matriz e motriz. O homem "pertence" a um espaço. "Ser de um certo lugar" não expressa vínculo de propriedade, mas uma rede de relações [...]. Se com a memória se explora a dimensão temporal do homem, com a "pertença" está em cena o conteúdo espacial da existência. Ora, sou o que sou num espaço ocupado, habitado e, numa palavra, apropriado por muitos outros muito antes de mim (MENESES, 1992, p.188, grifos meus).

Constitui a centralidade desta narrativa a compreensão da expressão corporal como uma linguagem, perspectiva crítico-superadora em educação física, formulada por um coletivo de autores - Carmen Lúcia Soares, Celi Nelza Zülke Taffarel, Elizabeth Varjal, Lino Castellani Filho, Micheli Ortega Escobar e Valter Bracht na obra Metodologia do Ensino de Educação Física (1992) - os quais compreendem as manifestações corporais "como formas de representação simbólica de realidades vividas pelo homem, historicamente criadas e culturalmente desenvolvidas" (Coletivo de Autores, 1992, p.38). As diversas formas de linguagem, de representação de mundo produzidas pela humanidade - como jogos, danças, folguedos, mímica e ginástica, por exemplo - puderam compor o conjunto de saberes e experiências cotidianas das crianças com o folclore.

Nesse percurso de trabalho, nos propusemos pensar ainda, como discute Jorge Larrosa Bondía, nos sujeitos como territórios de passagem, ou seja, sujeitos da experiência. Considerando esta como tudo aquilo que nos toca e nos transforma, procuramos permitir a aproximação das crianças aos acontecimentos que suscitam a imaginação e que assim requerem

[...] um gesto de interrupção, um gesto que é quase impossível nos tempos que correm: requer parar para pensar, parar para olhar, parar para escutar, pensar mais devagar, olhar mais devagar, e escutar mais devagar; parar para sentir, sentir mais devagar, demorar-se nos detalhes, suspender a opinião, suspender o juízo, suspender a vontade, suspender o automatismo da ação, cultivar a atenção e a delicadeza, abrir os olhos e os ouvidos, falar sobre o que nos acontece, aprender a lentidão, escutar aos outros, cultivar a arte do encontro, calar muito, ter paciência e dar-se tempo e espaço. (BONDÍA, 2002, p.24).

Apresentamos, assim, um relato de experiências construídas nesta aventura de pensar e fazer o cotidiano educativo, de dar vida e movimento ao folclore, possibilitando a imersão do novo e do inusitado nos tempos e espaços educativos (OLIVEIRA \& ROSA, 2000), lugares onde as 
crianças, por meio do contato com as diversas manifestações da cultura corporal, expressam múltiplas linguagens.

\section{COMO CHAMAR O SACI}

Qualquer ventania pode ser o sinal de um Saci na redondeza. Observar o vento com as crianças constitui uma interessante experiência para se perceber os fenômenos, as mudanças, os balanços, aquilo que voa, que chacoalha, o que resite e o que mostra sua leveza ao levitar no espaço. Depois de uma ventania, o que restou, caiu pelo chão, as descobertas, sair procurando os vestígios do que "o vento fez"... é algo mágico e encantador.

No início do dia, gostamos de receber as crianças no portão e darmos uma volta mais longa pelos arredores antes de entrarmos em nossa sala. Nesse percurso, vamos observando as árvores, as galinhas, as abelhas, os pássaros e as plantas e procuramos vestígios, achados, traços e pistas de suas passagens pelo entorno. Uma dessas pistas que povoou o chão de nossa escola foi a flor avermelhada de uma árvore, a Spathodea campanulata ou, "Chama da Floresta". O seu nome popular nos fez imaginar muitas coisas, já que o formato da flor lembrava um lume e poderia ser o facho luminoso da floresta, assim como os cabelos avermelhados do Curupira e os olhos ardentes do Boitatá. Esses gestos de parar, sentir, observar, encantar-se com o inusitado rapidamente fizeram com que a árvore entrasse para a nossa coleção de seres e coisas imaginárias, povoando nossas histórias e brincadeiras.

Os elementos encontrados caídos no chão - flores, folhas, sementes, penas, por exemplo costumam virar amuletos, talismãs, varas de condão, verdadeiros tesouros mágicos nas mãos das crianças. Foi brincando com esses amuletos que um dia elaboramos nossa mágica para chamar o Saci-Pererê.

Munidos de muitas flores e folhas secas nas mãos e, com os braços estendidos para o alto, invocamos para a roda do vento nosso cantor e compositor Dorival Caymmi, cantando e embalando: "Vamos chamar o vento! Vamos chamar o vento! Uuuh, uuuh!!"3, em seguida jogamos todos juntos as folhas ao alto. $O$ efeito da mágica é que em poucos segundos pode-se vislumbrar o vento dançando nas copas das árvores. Essa é uma descoberta que fizemos e incrivelmente sempre deu certo, às vezes o vento demora, mas as crianças repetem a dança quantas vezes for preciso até que possam se contentar com o mais leve sopro nas árvores.

É assim que trazemos o vento, ou os deslocamentos de ar que atraem o Saci. Há dias em que se venta muito 4 e as crianças observam movimentos e concluem: "Hoje tem muito Saci aqui na escola!" Ou "Os Sacis estão dando uma festa!".

Quando achamos pelo caminho brinquedos ou outros objetos fora dos lugares onde são guardados, logo atribuímos às peraltices do Saci, concluindo que ele está invisível rodeando nossa escola. Nesses momentos algumas crianças sagazes conseguem captá-lo num golpe de vista: "Eu vi! Eu vi o Saci, ele se escondeu ali atrás daquela árvore!!".

\footnotetext{
${ }^{3}$ Canção O Vento, disco "Caymmi e o mar", Odeon ( $\left.L P\right), 1949$.

${ }^{4}$ No Brasil, um tipo de vento local é o noroeste, massa de ar que sai do Amazonas e alcança o Estado de São Paulo entre agosto e outubro. Neste período de muitos ventos é possível visualizarmos rodamoinhos.
} 
Redemoinho. Redemoinho, vento circular. Remoinho, redemoinho, rodamoinho não é o pé-de-vento. O pé-de-vento é a lufada brusca, inesperada, que passa reboando. O remoinho é o vento em espiral, rodando como um parafuso gigantesco. Tem vida própria e atende às intercessões divinas. A origem, diz o povo, é o encontro de dois ventos. Briga de ventos, duelo, vadiação. No sul do Brasil é o Saci-Pererê o responsável pelos remoinhos. Salta no meio dos ventos e roda, gira, corcoveia, arrebatando folhas, garranchos, poeiras [...]. (CASCUDO, 1972 , p.771, grifos do autor).

Nesses dias de rodamoinhos, pés de ventos e corcoveados de Sacis, algumas bagunças acontecem, como o sumiço de brinquedos e pertences das crianças. Certa vez, ao retornarmos para nossa sala, tudo estava propositadamente espalhado pelo chão e a turma precisou guardar mochilas e brinquedos novamente nos lugares. Foi em um dia como esse que decidimos escrever um bilhete para o Saci, pedindo por favor para que não pegasse ou misturasse nossas coisas. Às vezes o travesso nos responde, dizendo que gosta de brincar e se divertir, outras vezes nem nos dá atenção. As crianças acham muito divertido, algumas esboçam uma pontinha de medo, outras curiosidade, entusiasmo e valentia: "Saci, eu vou pegar você!! Nós vamos arrancar seu gorro mágico!!!". E assim, por meio da brincadeira, os sentimentos são manifestados e os laços de parceria entre as crianças se estreitam, formando nossa percepção de grupo, uma vez que temos uma história que nos pertence.

Foi então que um dia resolvemos mostrar nossa astúcia e elaboramos um plano para engabelar o esperto do Saci.

\section{VAMOS CAÇAR SACI ${ }^{5}$}

Tivemos a ideia de nos disfarçar de Sacis e irmos até a "floresta" 6 para tentar aprisionar o danadinho dentro de uma garrafa de vidro, como ensina a lenda. Se conseguíssemos esta façanha, poderíamos pegar seu gorro mágico em troca de nossos objetos sumidos.

Para nosso disfarce fizemos máscaras de Sacis e combinamos que precisávamos pular com um pé só enquanto estivéssemos na floresta. Escolhemos um dia com mais ventos e uma das crianças teve a ideia de levarmos algumas peneiras usadas nas brincadeiras de areia no parque, já que esta é uma das estratégias para se capturar o Saci: jogando a peneira por cima de um rodamoinho.

Ficamos um tempo na "floresta" fazendo de conta que estávamos em festa, as "criançassacis" pulavam e faziam algazarras. Foi então que uma delas encontrou o gorro vermelho entre o bambuzal e veio ao nosso encontro mostrando-o como um troféu. Perguntei-lhe como conseguiu o gorro e ela me disse: "Fiquei perto do bambu com minha peneira, porque é ali que o Saci dorme. Acho que ele estava dormindo e não viu eu pegando o gorro dele".

\footnotetext{
${ }^{5}$ Faço aqui referência a uma interessante animação intitulada "Vou caçar Saci", produzida por Augusto Torrine, (Mito Sorocaba Produções, 2010) e que narra com traços delicados, com graça e engenhosidade a aparição e travessuras do Saci-Pererê.

${ }^{6}$ Chamamos "floresta" um espaço que há em nossa escola no qual realizamos diversas brincadeiras imaginárias. Tratase de um canteiro lateral onde há grandes árvores e arbustos plantados, dentre os quais um bambuzal. Em algumas regiões do Brasil explica-se que o Saci Pererê nasce no caule oco do bambu.
} 
Foi uma grande festa e imediatamente colocamos o gorro dentro da garrafa. As crianças fizeram uma roda para passar a garrafa de mão em mão. Algumas diziam: "O Saci está aí dentro, só que invisível" outras contestavam "Não está não, ele continua por aí e só ficou o gorro com a gente". Depois daquele momento de êxito e surpresas, saímos para o momento do lanche e deixamos a garrafa em cima da mesa. Não deu outra, quando voltamos a garrafa estava caída e aberta, o gorro do Saci havia sumido. Nosso orgulho durou pouco, mas a euforia continuou por muitos dias.

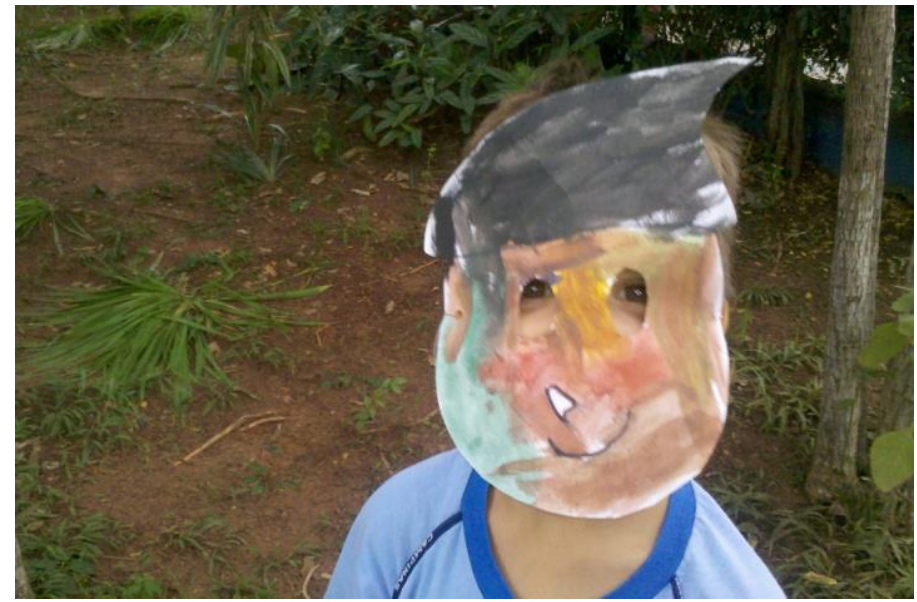

Figura 2: Disfarce de Saci (acervo pessoal, 2012).

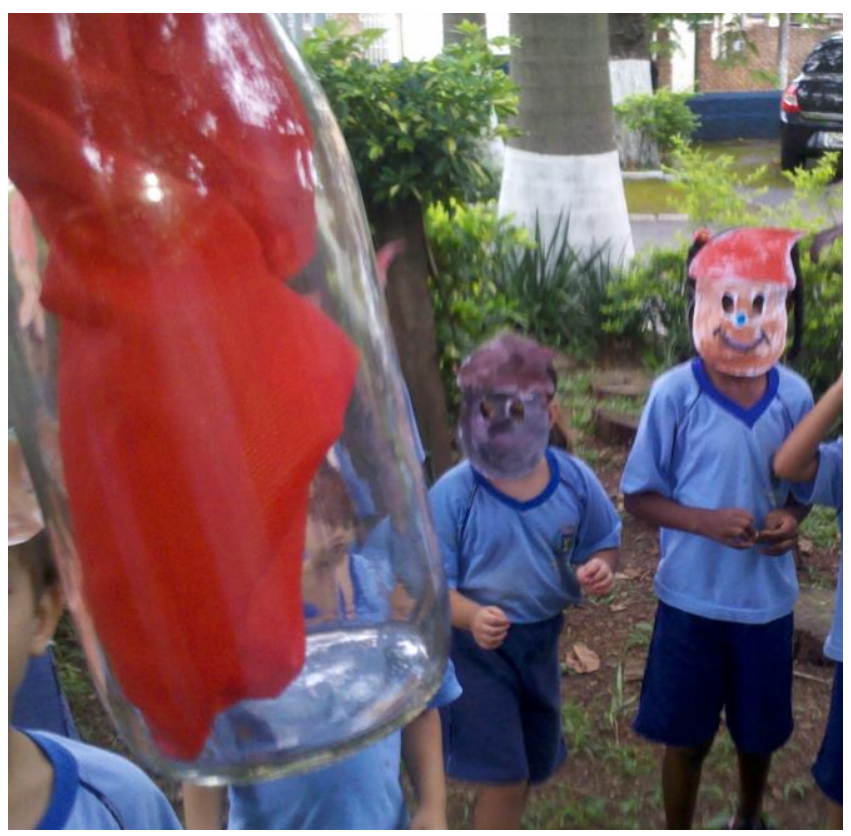

Figura 3: Saci na Garrafa (acervo pessoal 2012).

Durante a semana, percebi o quanto esta experiência foi marcante para as crianças, uma delas trouxe de sua casa outra garrafa vazia e me pediu para deixar na escola caso precisássemos capturar o Saci novamente. Outra criança pediu para a família fazer a "caça ao Saci" em casa e trouxe, para mostrar ao grupo, uma garrafa plástica com um Saci lá dentro. A mãe da criança me contou que a empolgação em casa foi tanta que ela decidiu costurar às escondidas um boneco do Saci para colocar dentro da garrafa. 
Envolver-se no faz de conta, criar possibilidades de sonho, encantamento e imaginação e liberdade é uma aventura, parte do desafio e descoberta de fazer-se professor/a, autores de nossas práticas pedagógicas. É nesse processo que tem como referência ações/experiências e reflexões/teorias que "o professor se percebe como sujeito autônomo e com autoridade para desenvolver sua prática pedagógica que é fruto de sua autoria docente" (CAPARROZ \& BRACHT, 2008 p.30).

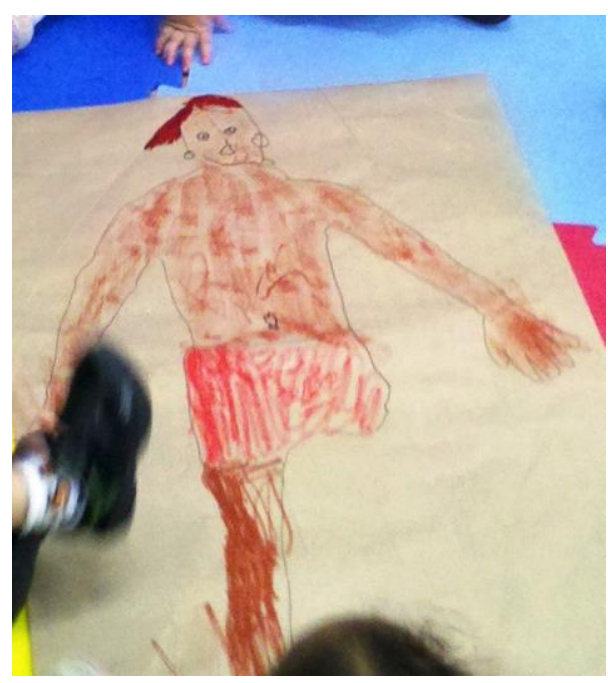

Figura 4: Desenho do Saci (acervo pessoal, 2013).

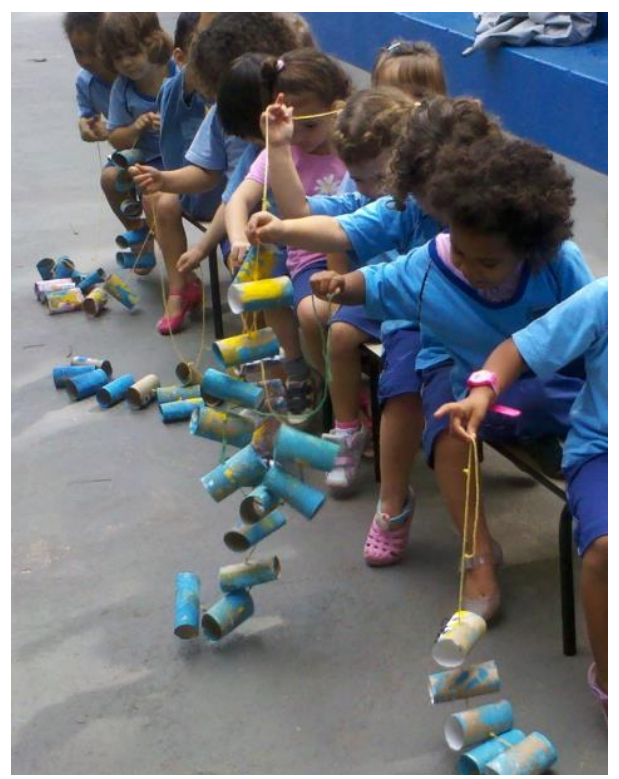

Figura 5: Levando Boitatá na floresta (acervo pessoal 2013).

Percebendo lugares de autorias e criações, outras brincadeiras foram acontecendo a partir desse singelo repertório folclórico o qual alimentamos e tomamos parte.

Dentre as inúmeras possibilidades de imaginar e brincar que foram se construindo e em diferentes espaços físicos, podemos citar, por exemplo, brincadeiras inventadas de pegar e saltar como "pega-pega do Saci e do Curupira", e "Saci sai da toca", além da descoberta de diferentes lugares para escalar, equilibrar-se e saltar, como aconteceu com uma das crianças que criou uma brincadeira de circuito no qual a turma teria que subir e descer em uma das árvores com a ajuda 
de uma corda amarrada por ela mesma. Ademais, citamos a confecção de brinquedos como a cobra "Boitatá" feita com sucatas; fantoches e bonecos de pano do Saci, dentre outros, os quais permitiram que as crianças levassem suas criações para casa e brincassem com os familiares e amigos.

Foi possível notar a inserção desses personagens folclóricos em desenhos feitos pelas crianças e também no enredo de suas brincadeiras. Algumas fizeram de conta que eram o Saci e usavam elementos encontrados no entorno para dar significado para suas ações. Uma dessas ocasiões, por exemplo, foi quando brincávamos com caixas de papelão de formas e tamanhos diferentes: ao ver que uma das caixas era pequena e vermelha, uma das crianças certificou-se que esta cabia em sua cabeça e fez dela um gorro. Logo saiu pulando com um pé só, gargalhando e fazendo peraltices com os amigos.

Oportunizar o acesso das crianças a essas práticas é sem dúvida função dos profissionais da educação, visto que as ações e as ideias adquiridas pelas crianças são provenientes do mundo social em que vivem, no qual estão presentes sobretudo a família, seu círculo de relacionamento e o currículo escolar, conforme salienta Kishimoto (1994 p.30),

\begin{abstract}
O conteúdo das representações simbólicas recebe, geralmente, grande influência do currículo e dos professores. Os conteúdos veiculados durante as brincadeiras infantis bem como os temas de brincadeiras, os materiais para brincar, as oportunidades para interações sociais e o tempo disponível são todos fatores que dependem basicamente do currículo proposto pela escola. Normalmente, a criança precisa de tempo para elaborar as ideias que encontra. E esse fator é bastante negligenciado pela maioria das escolas que privilegiam as atividades individuais orientadas.
\end{abstract}

É notável, neste trabalho, que as experiências suscitadas pelos gestos de ler, ouvir, contar, desenhar, cantar e dançar trouxeram situações significativas de encontro e convívio para o grupo, além de alargarem os tempos e os espaços das brincadeiras coletivas.

\title{
4 RODOPIOS NOS ESPAÇOS
}

No conjunto de saberes e práticas que aqui narramos, foi possível perceber o envolvimento não só das crianças mas também de adultos. Expandimos nossas experiências ao encontro de outras, como aconteceu com as famílias e demais funcionários da escola, seja confeccionando bonecos e gorros mágicos de Saci, seja colaborando nas artes de esconder, encantar, simular um faz de conta e participar desse grande "teatro da imaginação".

Com a ajuda desta equipe conseguimos fazer nosso boneco e mascote do Saci Pererê, que, dentro de uma sacola mágica com músicas, filmes, livros e fantoches, visitou a casa de cada criança. Em um caderno de registros, as famílias deixavam seus depoimentos, marcas, impressões de um trabalho cuja fantasia não se esgotava. Foi possível encontrar depoimentos como "Meu filho não queria mais largar a sacola, levou o boneco do Saci em todos os lugares, até no supermercado" ou ainda "Nunca havia pensado em contar as histórias do folclore para minha filha, foi mágico" e "Brincamos muito juntas, eu e minha filha, fazia tempo que eu não fazia mais isso...". 


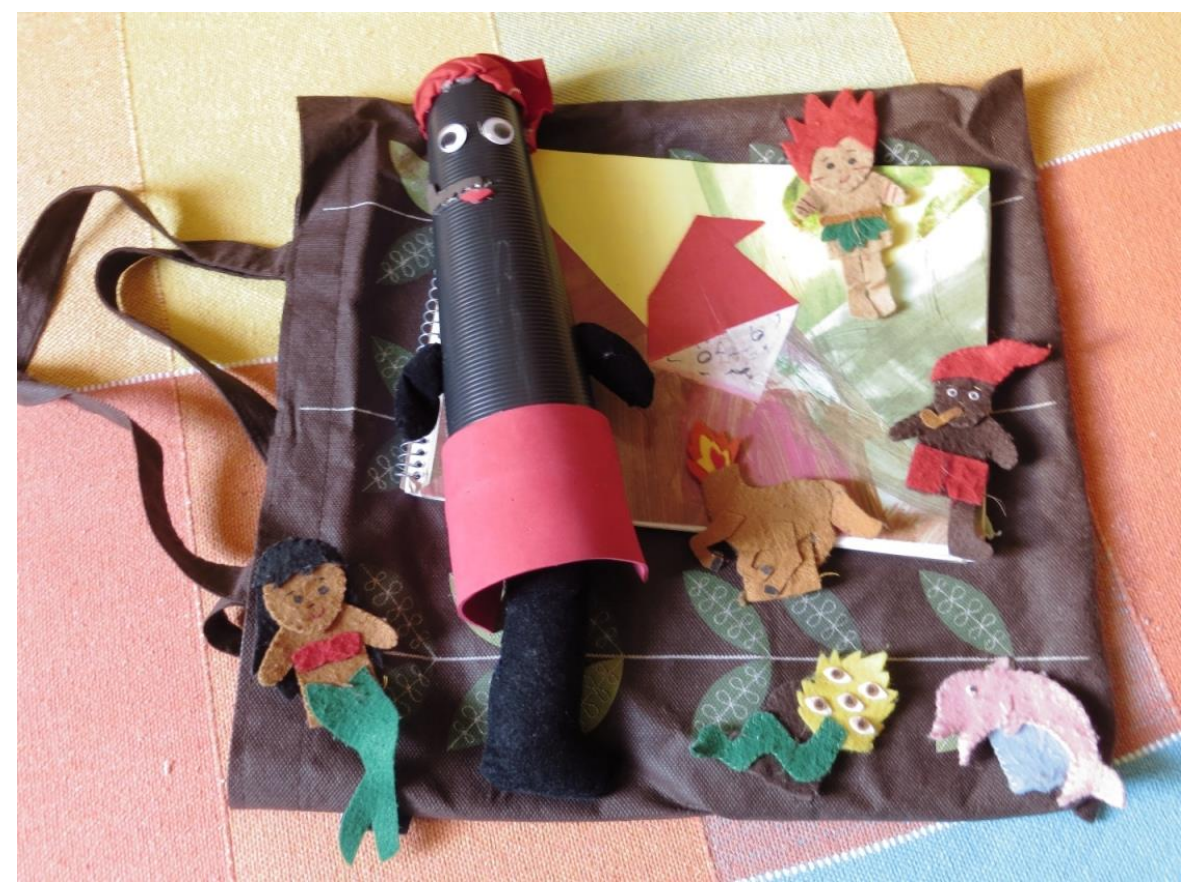

Figura 6: Sacola do Saci e seus amigos (acervo pessoal, 2013).

Concluímos então que a inserção de personagens do folclore no cotidiano infantil permite às crianças encontrarem tempo e espaço para imaginar e se transportar a outros mundos, inventar histórias e serem autoras de inúmeras experiências.

Ser Saci é transpor espaços, tempos, vasculhar e visitar lugares, rir com/dos outros e de si mesmo, sentir o aconchego de ouvir e contar histórias, alimentando as aventuras da oralidade. Termino aqui esse relato deixando outras brechas para a imaginação daqueles que vivenciam o cotidiano educativo com as crianças. Para isso, transcrevo o depoimento de Ruth Guimarães Botelho, caipira, moradora da cidade de Cachoeira Paulista7:

Ninguém pode viver sem uma explicação do mundo, e o saci é uma explicação do mundo, por isso nós precisamos do Saci. É um mito explicativo do mundo, ele explica determinadas coisas [...]. Todos esses duendes menores, esses duendes assim que não tem o que fazer e ficam por aí fazendo arte, eles servem para deixar a vida assim um encantatório, né. A vida tem que ser encantada. Quem não tem imaginação pra sonhar coisas, sonha com o Saci! Então é um mito do encanto.

\section{REFERÊNCIAS BIBLIOGRÁFICAS}

1. ANDRADE, M. de. O turista aprendiz. São Paulo: Duas Cidades, 1976.

2. AYOUB, E. Narrando experiências com a educação física na educação infantil. Revista Brasileira de Ciências do Esporte, 26(3), 143-158. Florianópolis, 2008. Disponível em: http://rbceonline.org.br/revista/index.php/RBCE/article/view/165/174. Acesso em: 09 jun. 2014.

3. BONDÍA, J. L. Notas sobre a experiência e o saber de experiência. Revista Brasileira de Educação, (19), 2002, 20-28. Disponível em: http://dx.doi.org/10.1590/S1413-

\footnotetext{
7 Depoimento transcrito do documentário: Somos todos Sacys. Direção: Sylvio Rocha e Rudá K. Andrade. São Paulo, Confraria Produções Artísticas, 28 abr.2005, 55min.
} 
24782002000100003. Acesso em: 09 jun. 2014.

4. BOSI, A. (Org.). Cultura brasileira: temas e situações. São Paulo: Ática, 2002.

5. CAPARROZ, F., BRACHT, V. O tempo e o lugar de uma didática da educação física. Revista Brasileira de Ciências do Esporte, 28(2), 21-37. Florianópolis, SC, 2008. Disponível em: http://rbceonline.org.br/revista/index.php/RBCE/article/view/53. Acesso em: 09 jun. 2014.

6. CASCUDO, L. da C. Redemoinho. In: Dicionário do folclore brasileiro (3a ed). Rio de Janeiro: Ministério da Educação e Cultura, 1973.

7. Geografia dos mitos brasileiros. Belo Horizonte, Brasil: Ed. Itatiaia; São Paulo: Ed. da Universidade de São Paulo, 1983.

8. COletivo DE AUTORES. Metodologia do ensino de Educação Física. São Paulo: Cortez, 1992.

9. KISHIMOTO, T. M. Jogos tradicionais infantis: O jogo, a criança e a educação. Petrópolis: Vozes, 1993

10. O jogo e a educação infantil. São Paulo, Brasil: Livraria Pioneira, 1994.

11. MEIRELES, C. Batuque, samba e macumba: Estudos de gesto e de ritmo 1926 - 1934. Rio de Janeiro: FUNARTE/Instituto Nacional do Folclore, 1983.

12. MENESES, U. B. de. Identidade cultural e arqueologia. In Bosi, A. (Org.). Cultura brasileira: Temas e situações (pp.182-190). São Paulo: Ática, 1992.

13. OLIVEIRA, J. A. de, ROSA, M. R. S. "Alevanta, Boi Dourado, Alevanta devagar...": Meninos e meninas brincando com o boi de mamão, fazendo-se grupo. In Ostetto, L. E.(org). (2000). Encontros e encantamentos na educação infantil: Partilhando experiências de estágios (pp.99118). Campinas: Papirus, 2000.

14. ROVERI, F. T. Barbie na educação de meninas: do rosa ao choque. São Paulo: Annablume, 2012.

15. VIEIRA, A. P. L. Cecília Meireles e a educação da infância pelo folclore. Dissertação (Mestrado). Universidade Federal Fluminense, Instituto de Ciências Humanas e Filosofia, Departamento de História, 2013, $182 f$.

\section{Meios Audiovisuais}

16. ROCHA, S., ANDRADE, R. K. (Diretores). Somos todos Sacys [filme documentário]. São Paulo: Confraria Produções Artísticas, 2005. Disponível em: http://vimeo.com/11609651. Acesso em: 09 jun. 2014.

17. TORRINE, A. (Produtor). Vou caçar Saci [filme animação]. Sorocaba: Mito Sorocaba Produções, 2010. Disponível em: http://vimeo.com/15044785. Acesso em: 09 jun. 2014. 